Int. J. Speleol., 32 (1/4) 2003: 33-42

\title{
MARTEL'S ROUTES IN MAMMOTH CAVE, KENTUCKY, 1912
}

\author{
Trevor R. SHAW ${ }^{1}$
}

\section{SUMMARY}

Martel's own copy of the Hovey 1912 guidebook to Mammoth Cave has his routes marked faintly in pencil on the printed cave plans. These plans are reproduced here, with his routes indicated on them. He generally followed the four standard tourist routes which now included Kaemper's 1908 discoveries to Violet City, but instead of visiting the Maelstrom he went to Hovey's Cathedral and Gerta's Grotto.

Keywords : caves, history, Mammoth Cave (Kentucky), E.A. Martel, Max Kaemper.

Edouard Alfred Martel is probably the most famous foreign cave person ever to go to Mammoth Cave in Kentucky. Yet not much has been published about this, and still less in English.

His visit took place in 1912, on 10, 11 and 12 October, and was described in detail by Martel (1914) himself. Randolph (1924) published photographs of him standing on a bridge near Mammoth Cave and also emerging from the entrance of Salt's Cave nearby. More recently the visit was mentioned briefly by Brucker and Watson (1976, p 294) and the barometric depth measurements made in the cave by Martel were discussed by Shaw (1991).

The broader subject of Martel's links with USA from 1894 onwards has been treated in two European publications (Shaw 1997; 1999), but for a detailed account of the visit itself it is still necessary to go back to his own classic description in Spelunca (Martel, 1914). That paper has never been published in English and so it is not widely read in America itself. Although one short paper (Martel, 1915) has been translated (Martel, 1969; 1981) it only summarizes his scientific conclusions and contains no record of which places he saw.

Recent examination of Martel's own copy of the Hovey (1912) edition of Mammoth Cave of Kentucky shows that he marked his route in pencil on the cave plans there. Some of the pencil marks are too faint to reproduce photographically, so

${ }^{1}$ Karst Research Institute, ZRC SAZU, Titov trg 2, SI-6230 Postojna, Slovenia e-mail : $\underline{\text { izrk@zrc-sazu.si }}$ 
copies of the plans are printed here with the routes he marked transferred on to them. These provide a convenient record of just where in the cave he did go, as well as reproducing the information contained in a unique Martel document.

\section{The 1912 Visit to USA}

Martel's first and only visit to USA took place in 1912. Already he had several friends and professional colleagues there (though Hovey was by then too old to accompany him), but the occasion of his 1912 visit was the Transcontinental Excursion in celebration of the $60^{\text {th }}$ anniversary of the American Geographical Society. The excursion lasted 57 days and covered more than $21000 \mathrm{~km}$. The main organizer was W.M. Davis who, 18 years later, was to write his classic paper on speleogenesis.

In order to visit Mammoth Cave, Martel had to leave the main excursion party and proceed on his own. He was with the rest at the Roosevelt Dam in Arizona on 5 October; but on 10,11 and 12 October he was at Mammoth Cave, while on the $13^{\text {th }}$ he was still in the area, taking altitude readings on the surface. Most probably Martel left the others on October 9 at Memphis, whence a single train journey would take him to Nashville (Tennessee) or Bowling Green (Kentucky) for Mammoth Cave. He was a guest of the management while he was there.

He followed almost all the regular tourist routes and also visited some other parts, as will be seen when his routes are discussed later. Using altitudes obtained from aneroid barometer readings, he was able to draw longitudinal sections of the cave as part of his attempts to understand the sequence of its formation.

\section{Martel's Copy of Hovey's Book}

Although the copy of Hovey's (1912) revised edition of the Mammoth Cave of Kentucky once owned by Martel does not bear his usual library stamp (Fig. 1), it is

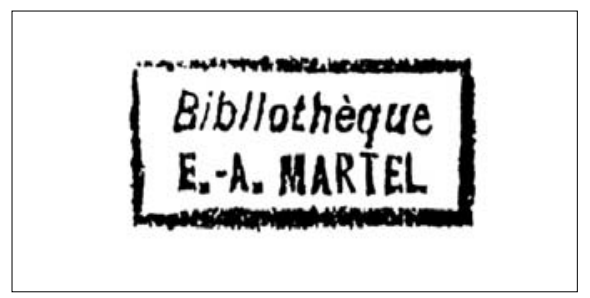

Fig. 1 - The library stamp found in most of Martel's books but not in his copy of Hovey (1912). Actual length $25 \mathrm{~mm}$.

known to have belonged to him for the following reasons. The book, now in the Library of the Karst Research Institute in Postojna, has the same provenance as three more of his books which do have his library stamp - via a Monsieur Charpentier of France, Henry Sotheran bookseller of London, and Trevor Shaw. Secondly it has a printed presentation slip pasted in, "Compliments of Horace C. Hovey." (one of the 
other books has a manuscript inscription to Martel by Hovey, reproduced in Shaw (1997, p. 37)). Finally, the routes marked in pencil on the maps in the book, while mainly the standard tourist trails, omit the one to the Maelstrom which Martel did not follow and do include the passages to Hovey's Cathedral and Gerta's Grotto which he visited although they are not normally shown.

Martel's copy of this book, given to him shortly after publication, is evidently of the first issue, for the binding, while generally similar to that of the later issue, does not have the author's name on the spine and there is a more complex decorative device beneath the title. The cover is of a slightly darker green, in vertically ribbed instead of smooth cloth, and the end-papers are patterned instead of plain. The copy in the British Library (10410.pp.22, received on 7 November 1912) is similar, reinforcing the idea that early copies were in this binding.

\section{The Cave Plans}

There are five plans in this 1912 revision of the book which had first appeared fifteen years earlier as Mammoth Cave of Kentucky an illustrated manual by Horace Carter Hovey and Richard Ellsworth Call (1897) and had contained only Call's plan dated 1897. That was the basis of the overall folding plan in the 1912 edition where many more passages had been added to Call's work. The whole plan, as published thus, was credited as "drawn by Horace C. Hovey 1909 (from former surveys, with recent additions)". It had first appeared in this form in Hovey's smaller guidebook of 1909. It had no scale. A note on this plan reads:

In the year 1908 Max Kaemper, a German Engineer, was employed to make a complete survey exclusively for the use of the owners. Some of his suggestions are embodied in this map of 1909; and others in the separate charts for the several routes.

That 1908 plan by Kaemper was never published complete until its appearance in 1981 as a facsimile of a redrawn copy (Kaemper, 1981), the cave owners being determined to withhold accurate locations of the passages to prevent neighbouring landowners from making entrances on their own land and so spoiling their monopoly. The folding Hovey plan is inaccurate in other ways, too, perhaps for the same reason.

Max Kaemper (1879-1916) came to the cave at the end of February 1908 as an ordinary visitor and completed the standard tours in two days. But he wanted to see more. Ed. Bishop, a black guide, showed him all the remote parts of the cave and they discovered new passages. The cave owners, realising that they themselves needed an accurate plan of the cave, allowed him to survey the whole of it in return for free accommodation. The task took him eight months and the resulting plan was more than a metre long. No scale or north point was added, for security reasons, and for more than 50 years it remained unknown in the cave archives. Kaemper's new discoveries included the passages beyond Hovey's Cathedral to Gerta's Grotto, etc., 
and beyond Ultima Thule to Violet City. He was also a competent cave photographer whose pictures, copyrighted by H.C. Ganter the cave manager, were used as postcards (Kliebhan, 1997; Kliebhan \& Thomas, 1999).

The other four plans in the book of 1912 (those reproduced here with Martel's routes on them) all owe a lot to the Kaemper survey. Those labelled Routes I, II and III and "copyright 1908 by H.C. Ganter" are all redrawn from Kaemper's plan, though their size prevents all the new place names being printed. The Route IV plan is just a part of the folding plan already described. It includes some of Kaemper's new passages beyond Hovey's Cathedral, but does not extend much beyond Gerta's Grotto. Where it has an open-ended passage marked "footprints" the original Kaemper plan continues to Sansom's Dome and Carrie's Pass.

Martel himself (1914, p. 274) has this to say about the printed versions (Routes I, II and III) of parts of Kaemper's plan. He had evidently not been allowed to see the original:

... three fragments of Kaemper's surveys (routes I, II and III) are exhibited below the balcony of Mammoth Cave Hotel and published in the latest edition of Hovey's guide : but, in accordance with the inflexible rule, they have neither scale nor orientation; reproducing them is forbiden and I have even heard that certain alterations have been intentionally made to render it impossible to locate on the surface the positions of passages below.

\section{Martel's Routes}

The translated title of Martel's main 1914 paper is "Explanations ('Explications') concerning the Mammoth Cave 1912". Thus its purpose is not to be just a visit report or account of what he did, but to present his views on the interrelation of the various passages at their different levels and also their formation. With his breadth of experience and knowledge of caves in Europe, he was the best person to attempt this at the time. He was, of course, hindered by not being allowed access to the only accurate plan then excisting.

The places named in that text are therefore not necessarily in the order in which he saw them, being linked more by morphology than by tourist routes. Thus:

Here the excursion continues by way of the rivers to Route IV and the two most remote extremities of Mammoth Cave; but, to make our hypothesis on the formation of the cave easier to follow, it is necessary to remain with the Main Cave. (Martel, 1914, pp. 257-258).

Referring to his own movements, he writes:

I followed all four routes, with one variant : turning left at 
Mary's Vineyard in order to visit the new and difficult-to-reach area of Hovey's Cathedral (which is not prepared for public visits) instead of that of the Maelstrom: (Martel, 1914 p. 246)

Beyond Hovey's Cathedral he went on to Gerta's Grotto, discovered by Kaemper and named by him after his cousin.

Figs. 2 to 5 reproduce the plans showing routes I to IV from the 1912 guide (Hovey, 1912), with the pencil route markings in Martels' own copy transferred on

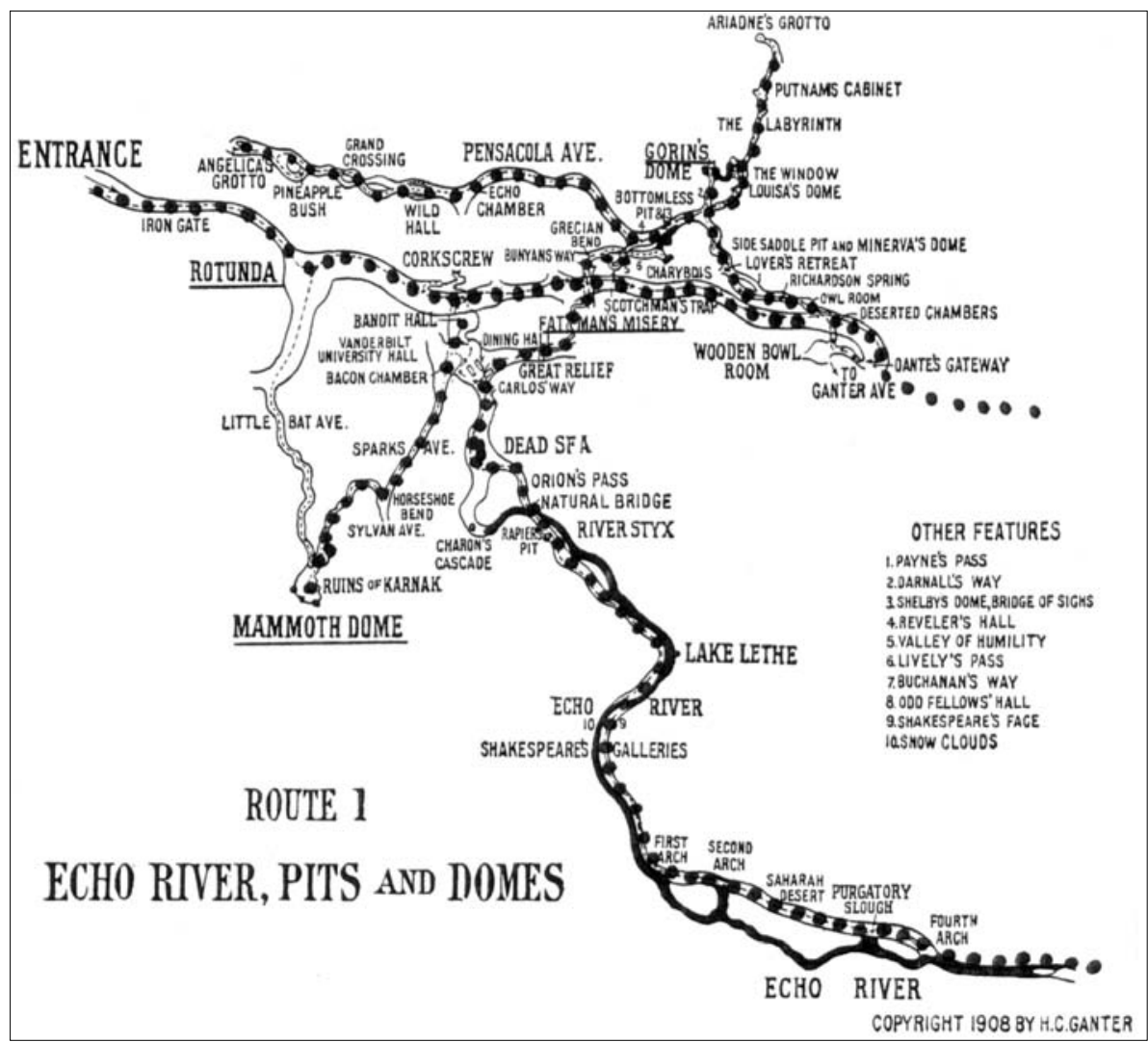

Fig. 2 - The standard tourist Route I reproduced from Hovey (1912), with the route that Martel marked on his own copy shown here by heavy dots and with some place names underlined as he did. The tourist route is indicated on the printed original by fine dashed lines.

to them. They are here indicated by heavy dots, for not only would Martel's pencil lines be difficult to distinguish from the lines of the plan, but some are very faint : indeed in some places the pencil seems to have broken and there is only an indented line on the paper. Where his hastily sketched lines have diverged from the passages and cut corners, the dotted lines here have followed the normal route. To denote pas- 


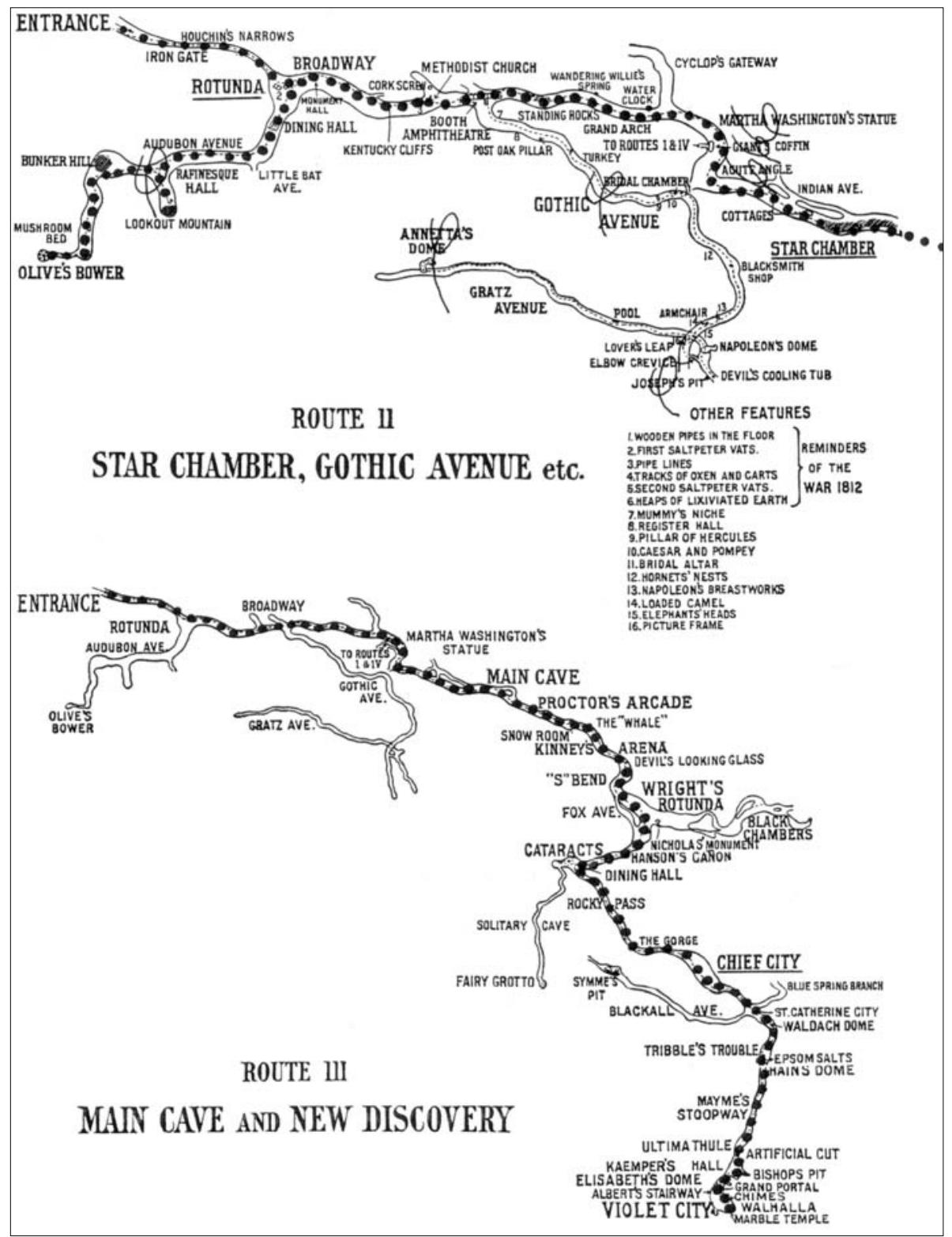

Fig. 3 - Route II, with Martel's route shown by a heavy dotted line or by his special symbol where he turned and retraced his steps. Two place names are underlined as in his copy.

Fig. 4 - Route III with Martel's own route shown. In his own copy of the book, the line from the entrance to beyond Chief City is marked only by an indented line as if his pencil had broken at Mayme's Stoopway. Chief City is underlined as in his copy. 


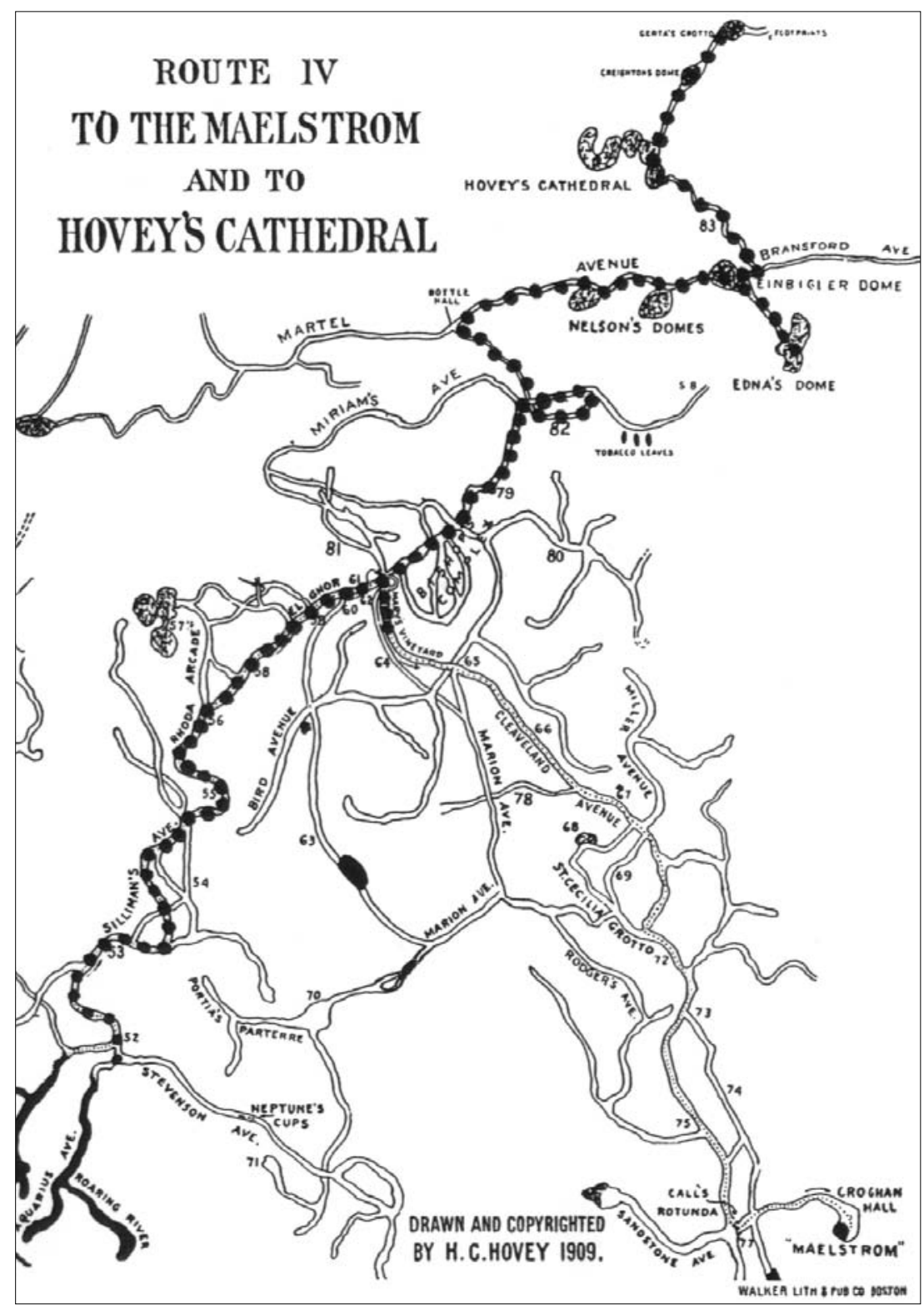

Fig. 5 - Route IV. It will be seen that Martel left the normal route at Mary'sVineyard and went to Hovey's Cathedral and beyond, instead of to the Maelstrom.

sages where he turned back and retraced his steps he has used a curly manuscript symbol resembling an "o" with tails or an inverted Greek lower case letter gamma, prominent in Figs. 2 and 3. These are present in Gothic Avenue and Gratz Avenue 
without there being pencil lines along these passages, and are sufficient indication by themselves that he had been there.

A facsimile of one of the plans (Route II) with Martel's own pencil markings on it is reproduced here as Fig. 6. It shows some of the rough lines by which he indi-

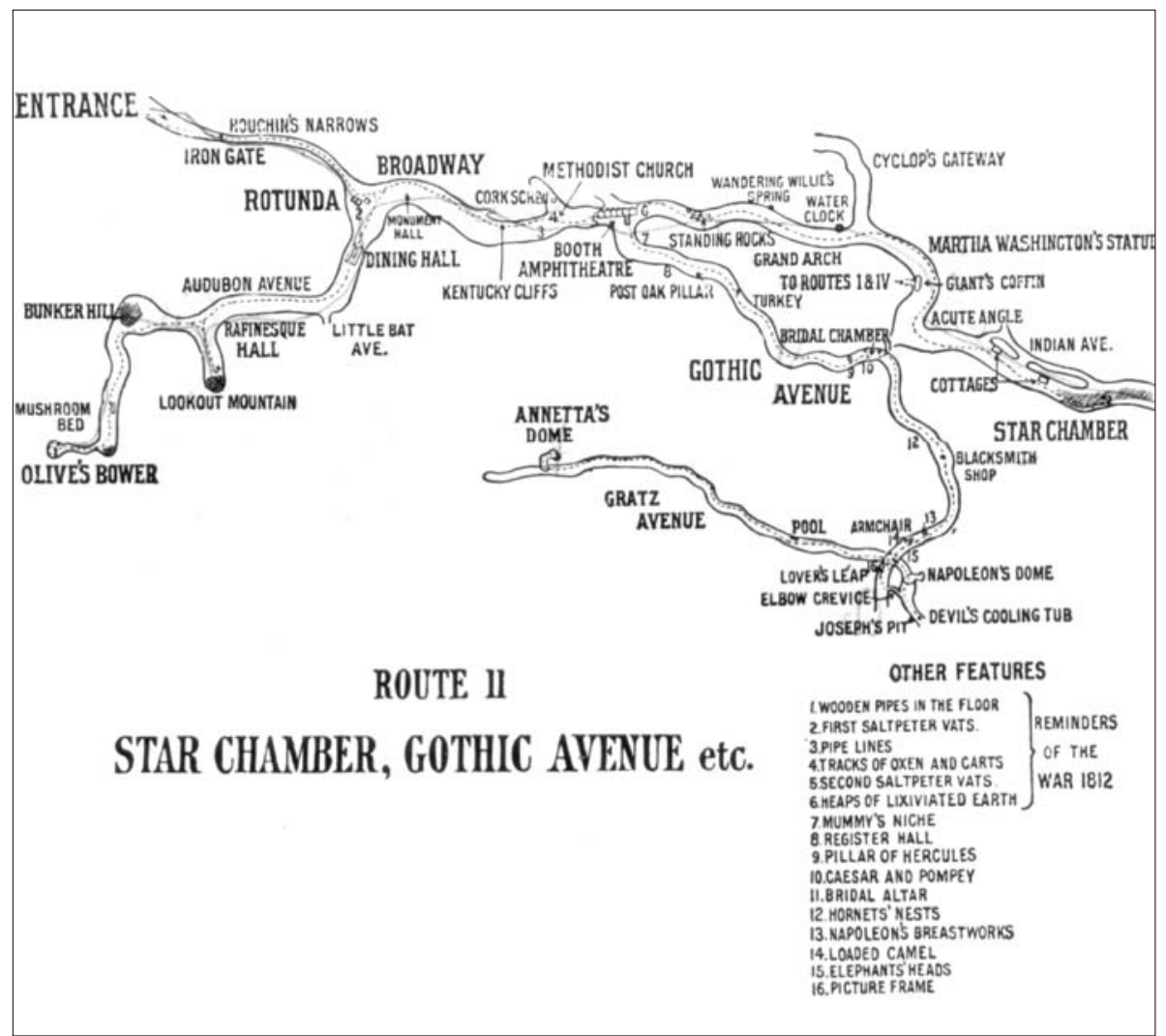

Fig. 6 - A facsimile of Martel's own copy of the Route II plan, with his pencil marks enhanced photographically by Marko Zaplatil of ZRC-SAZU in Ljubljana.

cated his route and also the special symbol mentioned above as showing where he turned back.

Printed below is a list of the principal parts of the cave seen by Martel and named in his 1914 text, spelled as he wrote them, mostly in English. As already explained, these places are referred to in the course of his discussions and do not necessarily follow the sequence in which he saw them. To link the places to the regular routes, and hence the approximate order in which he came to them, each one is followed here by the number of the route on which it was normally visited. Some other places, such as the Maelstrom, are mentioned in discussion although it is known that he did not visit them. 
Entrée [Entrance], Rotonde [Rotunda] (I, II, III), Audoubon Avenue (II), Little Bat Avenue (I), Corkscrew (I, II), Bandit Hall (I), Bacon Chamber (I), Spark's Avenue (I), Mammoth Dome (I), Booth's Amphitheatre (II), Gothic Avenue (II), Gratz Avenue (II), Annette's Dome (II), Napoleon's Dome (II), Main Cave (II, III), Standing Rocks (II), Martha Washington Statue (II), Giant's Coffin (II), Dante's Gateway (I), Wooden Bowl Room (I), Labyrinth (I), Bottomless Pit (I), Gorin's Dome (I), Pensacola Avenue (I), Scotchman's Trap (I), Fat Man's Misery (I), Dead Sea (I), Cascade to Charon (I), Procter's Arcade (III), Wright's Rotunda (III), Cataracts (III), Chief City (III), Ultima Thulé (III), Artificial Cut (III), Puits de Bishop [Bishop's Pit] (III), Violet City (with a drawing based on a sketch by Martel) (III), Styx River (I), Pont Naturel [Natural Bridge] (I), Lac Léthé (I) Echo River (with a drawing based on a sketch by Martel) (I), Ganter Avenue (I), Serpent Hall (IV, but not named on the map in Hovey 1912), Rhoda's Arcade (IV), El' Ghor (IV), Mary's Vineyard (IV), Bottle Hall (IV), Hovey's Cathedrals (with a drawing based on a sketch by Martel) (IV), Creighton's Dome (IV).

\section{REFERENCES}

BRUCKER, R.W. \& R.A. WATSON. 1976. The longest cave. A.A. Knopf, pp.xx.316, xi, [ii], New York.

HOVEY, H.C. 1909. Hovey's hand-book of the Mammoth Cave of Kentucky. - a practical guide to the regulation routes. J. P. Morton, pp. 63, [i] Louisville.

HOVEY, H.C. 1912. Mammoth Cave of Kentucky (Hovey and Call) with an account of Colossal Cavern. J.P. Morton, pp.v, 131, Louisville.

HOVEY, H.C. \& R.E. CALL. 1897. Mammoth Cave of Kentucky an illustrated manual. J. P. Morton, pp. v, [i], iii, [i], Louisville.

KAEMPER, M. 1981. Map of the Mammoth Cave Kentucky surveyed and drawn by Max Kaemper, Berlin Germany (guide : Ed. Bishop) 1908 redrafted by Diana O. Daunt. Cave Research Foundation, f.1, 71 x 123 cm., [Washington,D.C.?].

KLIEBHAN, B. 1997. Max Kämper und seine Vermessung der Mammoth Cave im Jahre 1908. Die Höhle, 48 (4) : 101-109, Wien.

KLIEBHAN, B. \& N. THOMAS. 1999. Searching for Max[,] the engineer, the war and the 
world's longest cave. www.kliebhan.de/spelhist/max-e.htm (based on a German radio programme of 26 December). A hard copy is held in the library of the Karst Research Institute, Postojna.

MARTEL, E.A. 1914. Explications sur Mammoth Cave 1912. Spelunca [,]Bulletinet Mémoires de la Société de Spéléologie, 9 (74) for December 1913: 239-302, Paris.

MARTEL, E.A. 1915. Sur Mammoth Cave (Kentucky). Comptes Rendus des séances de l'Academie des Sciences, 159 : 1013-1016, Paris.

MARTEL, E.A. 1969. On Mammoth Cave, Kentucky. Trans. F.J. Dickey. TheJournal of Spelean History, 2 (1) : 5-6, Seattle.

MARTEL, E.A. 1981. On Mammoth Cave, Kentucky. Trans F.J. Dickey. Pp. 15-16 in WATSON, R.A. (ed.) - The Cave Research Foundation [.] Origins and the first twelve years 1957-1968. Cave Research Foundation, pp. 465, 29, Mammoth Cave (This is the same translation as in Martel, 1969).

RANDOLPH, H.F. 1924. Mammoth Cave and the cave region of Kentucky. Standard Printing Company, pp. 153, [iii], Louisville.

SHAW, T.R. 1991. Barometric depth measurements in Mammoth Cave. The Journal of Spelean History, 25 (3) : 33-44, Arlington.

SHAW, T.R. 1997 [=2000] Martel's links with USA. International Journal of Speleology, 26 (3-4) : 29-48, Roma.

SHAW, T.R. 1999. Edouard-Alfred Martel et les Etats-Unis d'Amérique. Pp.357-374 in D. ANDRÉ (ed.) - L'homme qui voyageait pour les gouffres[.] Actes du Colloque tenu à Mende les 17 et 18 octobre 1997, Archives Départementales de la Lozère, pp. 421, Mende.

Received: 5 july 2003

Accepted: 12 september 2003 